\begin{tabular}{cccc} 
VERSITA & GOSPODARKA & SUROWCAMI & MINERALNYMI \\
\hline Tom 29 & 2013 & Zeszyt 4 \\
& & \\
& DOI 10.2478/gospo-2013-0046 &
\end{tabular}

\title{
The geological aspects of meta-lignite and sub-bituminous coal occurrences in Poland within the context of deposits and uneconomic occurrences in Europe
}

\begin{abstract}
Introduction
The term "brown coal" is commonly identified with a low rank coal variety, the domestic deposits of which originate mainly in the Polish Lowland. Actually, it is a raw material which has great importance to the Polish energy balance as it accounts for $23 \%$ of domestic energy production, including $40 \%$ of electrical power production. This coal is comprised of a variety of types classified as soft brown coal, whereas in nature higher rank varieties also occur, known in Poland and many other (particularly European) countries as "hard brown coal". Such classification is accepted in Poland according to German rules (i.e. Kowalski, Rosiński 1957).

Hard brown coal, like its lower rank varieties, is a sedimentary rock mainly of vegetable

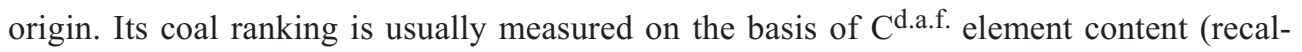
culated to dry, ash-free basis - d.a.f.), or on the basis of average, random reflectivity $\left(\mathrm{R}_{\mathrm{r}}{ }^{\mathrm{o}}\right)$ of its dominant petrographic component (ulminite $\mathrm{B} /$ vitrinite), which places it between soft brown coal and bituminous coal. In the classification accepted in Poland, it is divided into dull brown coal and bright brown coal. The dull variety of brown coal has features (particularly petrographic features) similar to soft brown coal, and the bright type corresponds with bituminous coal. Thus, these varieties are classified and described according
\end{abstract}

* Ph.D.Sc. Eng., AGH University of Science and Technology, Faculty of Geology, Geophysics and Environmental Protection, Kraków, Poland; e-mail: wagner@geol.agh.edu.pl 
to different schemes in different countries. Ultimately, this variety of coal is classified according to rules established by the ECE (Economic Commission for Europe, United Nations), which follow the American standard ASTM. According to this standard, dull varieties are described on a lithological and petrographic basis, identically in the case of the soft brown coal called ortho-lignite; whereas dull and bright varieties called meta-lignite and sub-bituminous coal are described as bituminous coal. Some countries possessing this raw material follow other classifications but based on similar assumptions. Some of these are similar to German nomenclature (for example, Russia and its former republics or the Balkan countries), whereas others follow the American standard. There is, in fact, a need for a worldwide, unified description of brown coal. Such efforts were undertaken in the year 1957, when the ECE-UN developed the brown coal classification "Mining and Upgrading of Brown Coal in Europe. Developments and prospects" which, with some modifications, was accepted as the standard ISO 2950 in 1970 (Libicki, Szczepiński 2007).

TABLE 1

Comparison of the international classification of coal and the previous classifications applicable in Germany and Poland

TABELA 1

Porównanie klasyfikacji międzynarodowej węgla ze stosowanymi w Niemczech i Polsce

\begin{tabular}{|c|c|c|c|}
\hline Germany & Poland & $\begin{array}{c}\text { ISO } 11760, \\
\text { PN-ISO } 11760\end{array}$ & Controlled conditions \\
\hline Torf & Torf & - & - \\
\hline $\begin{array}{c}\text { Soft brown coal } \\
\text { (Weich-braunkohle) }\end{array}$ & $\begin{array}{c}\text { Soft brown coal } \mid \\
\text { (miękki węgiel brunatny) }\end{array}$ & Ortho-lignite & $\begin{array}{c}\mathrm{W}_{\mathrm{t}}{ }^{\mathrm{maf}} 35-75 \% \text { wag. } \\
\mathrm{Q}_{\mathrm{s}}{ }^{\mathrm{maf}}<15 \mathrm{MJ} / \mathrm{kg} \\
\mathrm{R}_{\mathrm{r}}{ }^{\circ}<0.20 \% \\
\mathrm{C}^{\text {daf }} \text { (huminite) }<71 \% \text { wag. }\end{array}$ \\
\hline $\begin{array}{l}\text { Dull brown coal } \\
\text { (Matt-braunkohle) }\end{array}$ & $\begin{array}{l}\text { Hard dull brown coal } \\
\text { (matowy twardy węgiel } \\
\text { brunatny) }\end{array}$ & Meta-lignite & $\begin{array}{c}\mathrm{W}_{\mathrm{t}}^{\mathrm{maf}}<35 \% \mathrm{wag} \\
\mathrm{Q}_{\mathrm{s}}{ }^{\mathrm{maf}}>15-20 \mathrm{MJ} / \mathrm{kg}, \\
\mathrm{R}_{\mathrm{r}}^{\mathrm{o}}-0.40 \% \\
\mathrm{C}^{\text {daf }} \text { (huminite) } \sim 71-74 \% \text { wag. }\end{array}$ \\
\hline $\begin{array}{l}\text { Bright brown coal } \\
\text { (Glanz-braun kohle) }\end{array}$ & $\begin{array}{l}\text { Hard bright brown coal } \\
\text { (błyszczący twardy węgiel } \\
\text { brunatny) }\end{array}$ & $\begin{array}{l}\text { Sub-bituminous } \\
\text { coal }\end{array}$ & $\begin{array}{c}\mathrm{Q}_{\mathrm{s}}^{\mathrm{maf}}=20-24 \mathrm{MJ} / \mathrm{kg}, \\
\mathrm{R}_{\mathrm{r}}{ }^{\mathrm{o}}=0.41-0.50 \% \\
\mathrm{C}^{\text {daf }}(\text { vitrinite }) \sim 76 \% \mathrm{wag} .\end{array}$ \\
\hline $\begin{array}{l}\text { Bituminous coal } \\
\text { (Steinkohle) }\end{array}$ & $\begin{array}{l}\text { Bituminous coal } \\
\text { (węgiel kamienny) }\end{array}$ & Bituminous coal & $\begin{array}{c}\mathrm{R}_{\mathrm{r}}{ }^{0}-0.51 \% \\
\mathrm{C}_{\text {daf }}(\text { vitrinite })>76 \% \text { wag. }\end{array}$ \\
\hline
\end{tabular}

$\mathrm{W}_{\mathrm{t}}^{\text {maf }}$ - total moisture in coal recalculated to ash-free basis, $\mathrm{Q}_{\mathrm{s}}$ maf - Gross Calorific Value recalculated to total moisture and ash-free basis, $\mathrm{R}_{\mathrm{r}}{ }^{\mathrm{O}}$ - random reflectivity of ulminite $\mathrm{B} /$ vitrinite 
Further efforts at unifying brown coal classification on an international scale resulted in a number of proposals, until finally in 1998 the classification "International Classification of In-Seam Coals and International Codification System for Low-Rank Coal Utilization" was developed, described in the document with the signature of ECE-UN/ENERGY/50, 2002. Settlements outlined in these documents are also mentioned in the standard ISO 11760:2005 and domestic standard PN-ISO 11760:2007.

The aforementioned classification and cited standards combine lithologic-petrographic and technological aspects of the coal, following the American nomenclature system.

However, the limits of coalification have been unified (for example: soft brown coal, dull hard coal, bright hard coal) within the American system (Table 1).

The present study summarizes the state of actual knowledge, mostly in Poland, including a very important element of the coalification sequence, indicating that hard brown coals = $=$ meta-lignite and sub-bituminous coal. Their uneconomic occurrences in Poland are observed, but without economical meaning. This study was based on domestic documentation (among others: Matl 1981; Gabzdyl 1995; Piwocki 2004; et al.), as cited mainly in publications covering the state of knowledge from the 1960s to the 1970s. It does not reflect current Polish publications (which particularly relate to the assessment of the coalification degree of those rare occurrences of meta-lignite and sub-bituminous coal in Poland), but completes, for example, the picture of Mesozoic and Cenozoic coal-bearing mega regions of Europe.

\section{Significant features of meta-lignite and sub-bituminous coal in comparison with ortho-lignite}

Meta-lignite and sub-bituminous coal are classified as caustobioliths with a higher coal rank than in the case of ortho-lignite (soft brown coal), but with a lower coal rank than in the case of bituminous coal. Thus, these types of coal demonstrate an intermediate character which is reflected in their physical-chemical features.

This intermediate character is evident in the appearance of the coal. Meta-lignite and sub-bituminous coal varieties are coloured in a dark shade of brown or are black and bright as a result of strong geochemical gelification. However, the streak colour (powdered coal) is its important identifying feature, which is always brown in colour - brighter in dull varieties and darker in bright varieties. Meta-lignite and sub-bituminous coal have distinctly lower total moisture (20-35\% per weight) and considerably higher gross calorific value when compared with soft varieties (Table 2). Thus it is a coaly raw material of considerably higher technological quality than in the case of soft varieties, with comparable ash content and total sulphur range. 
Identification features in various types of humic low-rank coals with varying rank

TABELA 2

Cechy identyfikacyjne węgla brunatnego w różnych odmianach humusowego węgla brunatnego

\begin{tabular}{|c|c|c|c|}
\hline \multirow{3}{*}{ Poland } & \multicolumn{3}{|c|}{ Brown coal } \\
\hline & \multirow{2}{*}{ soft } & \multicolumn{2}{|c|}{ hard } \\
\hline & & dull & bright \\
\hline $\begin{array}{l}\text { International Classification } \\
\quad(\text { ECE UN, 2002) }\end{array}$ & ortho-lignite & meta-lignite & sub-bituminous coal \\
\hline Colour & $\begin{array}{l}\text { light and dark brown, } \\
\text { rarely black }\end{array}$ & dark brown, black & black \\
\hline Lustre & $\begin{array}{c}\text { dull lustre (to total moisture) } \\
\text { eggshell glossy and glassy } \\
\text { (skin-dried basis) }\end{array}$ & $\begin{array}{l}\text { dull lustre, lustrous } \\
\text { (dry basis) }\end{array}$ & $\begin{array}{l}\text { glossy up to dull lustre } \\
\text { according to change } \\
\text { of lithotypes }\end{array}$ \\
\hline Streak & light brown & dark brown & $\begin{array}{c}\text { dark brown } \\
\text { with tint black }\end{array}$ \\
\hline Bedding & $\begin{array}{l}\text { indistinctive bedding, } \\
\text { mostly massive }\end{array}$ & $\begin{array}{l}\text { more or less bedding } \\
\text { (fibrous schistosity) }\end{array}$ & schistaceous \\
\hline Total moisture $\left(\mathrm{W}_{\mathrm{t}}^{\mathrm{r}}\right)$ & $\begin{array}{c}\text { very moist } \\
\text { (average } 50 \% \mathrm{wt})\end{array}$ & $\begin{array}{c}\text { moist } \\
\text { (average 35\% wt) }\end{array}$ & $\begin{array}{c}\text { low moist } \\
\text { (average to } 20 \% \mathrm{wt})\end{array}$ \\
\hline $\begin{array}{c}\text { Gross Calorific Value } \\
\left(\mathrm{Q}_{\mathrm{S}}{ }^{\mathrm{maf}}\right)\end{array}$ & $8.0-16.0 \mathrm{MJ} / \mathrm{kg}$ & $16.0-20.0 \mathrm{MJ} / \mathrm{kg}$ & $20.0-24.0 \mathrm{MJ} / \mathrm{kg}$ \\
\hline $\begin{array}{c}\text { Random reflectivity } \\
\text { of ulminite / vitrinite }\left(\mathrm{R}_{\mathrm{r}}{ }^{\circ}\right)\end{array}$ & $0.20-0.32 \%$ & $0.32-0.40 \%$ & $0.40-0.50 \%$ \\
\hline
\end{tabular}

$\mathrm{W}_{\mathrm{t}}^{\mathrm{r}}$ - natural total moisture in coal (in deposit), $\mathrm{Q}_{\mathrm{s}}{ }^{\mathrm{maf}}-$ Gross Calorific Value recalculated to total moisture and ash-free basis.

\section{Presence of meta-lignite and sub-bituminous coal in European deposits}

In general in Europe, the higher rank brown coal varieties occur in continental platform Mesozoic sediments, as well as in orogenic Mesozoic-Cenozoic sediments of the Alpine orogenic system. The only exception are the lower Carboniferous deposits of meta-lignite and sub-bituminous coal occurring on the Russian platform within the Moscow district (Moscow Coal Basin), in the area of the so called Great Donbas - Ukraine, as well as Upper Carboniferous occurrences within the Central Massive of France (e.g. Bas Dauphine Fig. 1).

The Mesozoic distribution of the main lands that support the coal bearing capacity of this epoch is associated with paralic Triassic, Jurassic, and Cretaceous beds. Triassic and 


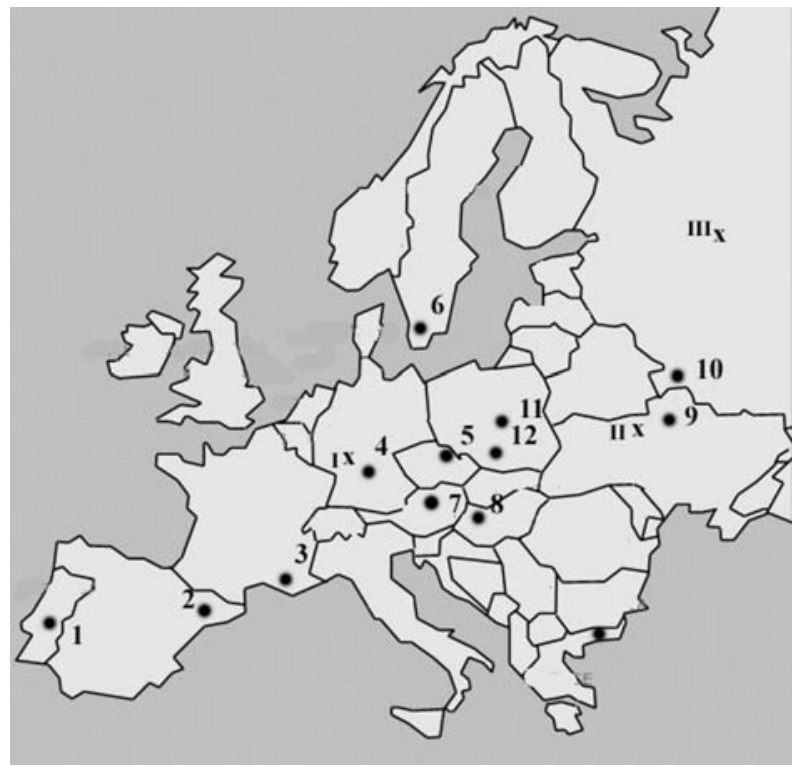

Fig. 1. Distribution of main Paleozoic and Mesozoic meta-lignite and sub-bituminous coal deposits and their uneconomic occurrences in Europe. Coal ranking is presented in Table 3

Paleozoic and Mesozoic coal deposit and uneconomic occurrences: 1 - Coimbra-Abrantes (Portugal), 2 - Utrillas (Spain), 3 - Fuveau (France), 4 - Mittelborn (Germany), 5 - Moravska Trebova (Czech Republic), 6 - Heganes (Sweden), 7 - Fohnsdorf (Austria), 8 - Ajka (Hungary),

9 - Trostyanets, Novoselytsya, Karaperovsk (Ukraine), 10 - Bielgorod-Obojansk (Russia), 11 - northern fringe of the Holy Cross Mountains, 12 - Jurassic Kraków Monocline (Zawiercie), Carboniferous: I - Bas Dauphine (France), II - The Great Donbas (Ukraine), III - The Moscow Basin (Russia)

Rys. 1. Ważniejsze paleozoiczne i mezozoiczne złoża twardego węgla brunatnego i jego niezłożowe występowania w Europie. Stopień uwęglenia węgla przedstawiono w tabeli 3

Jurassic sediments prevail in the areas of Eastern Asia, Southern Africa, and also North America, South America, and the Antarctic; whereas Cretaceous sediments prevail in North America where coal-bearing sediments containing meta-lignite and sub-bituminous coal are associated with the so called Gondwana Hemisphere, including Permian sediments (Pendliakow 1954; Gabzdyl 1989). In Europe, Permian and Mesozoic coal bearing capacity is poor, being only the repercussion of considerable coal bearing capacity on other continents. As mentioned, this is caused mainly by the supremacy of sea sediments. As a consequence, the meta-lignite and sub-bituminous coal occurring in European countries are small and medium scale, but the sea regression episodes are distinctly marked.

The Cretaceous and Paleogene deposits of meta-lignite and sub-bituminous coal occurring in Europe are related with Alpine orogenic areas, similar to other continents. They occur mainly within alpine foredeep and intermontane basins, and their higher coalification results mostly from the influence of magmatic phenomena which are related to all phases of orogene development. These deposits are frequently classified as polycyclic deposits, i.e. meta-lignite and sub-bituminous coal occurs only at the top of the regional coal formation; 
TABLE 3

List of the most significant deposits of meta-lignite and sub-bituminous coal in Europe excluding Polish territory (compiled by Matl 1981; Gabzdyl 1995; and own material)

Zestawienie ważniejszych złóż twardego węgla brunatnego w Europie bez terytorium Polski

(Matl 1981, Gabzdyl 1995, własny materiał)

\begin{tabular}{|c|c|c|c|c|}
\hline $\begin{array}{c}\underline{\text { State }} \\
\text { Basin (deposit) }\end{array}$ & Stratigraphy & $\begin{array}{l}\text { Number } \\
\text { of seams }\end{array}$ & $\begin{array}{l}\text { Average thickness } \\
\text { of seams }[\mathrm{m}]\end{array}$ & Variety of coal ranking \\
\hline 1 & 2 & 3 & 4 & 5 \\
\hline$\underline{\text { Portugal Coimbra-Abrantes }}$ & Upper Jurassic & $2-4$ & n.d. & meta-lignite \\
\hline$\frac{\text { Spain }}{\text { Utrillas }}$ & Early Cretaceous & $7-13$ & $2.2-6.0$ & sub-bitiminous coal \\
\hline $\begin{array}{l}\frac{\text { France }}{\text { Fuveau (du Larzac) }} \\
\text { Manosque } \\
\text { Central Basin-Bas Dauphine }\end{array}$ & $\begin{array}{c}\text { Jurassic } \\
\text { Miocene } \\
\text { Upper } \\
\text { Carboniferous }\end{array}$ & $\begin{array}{c}4 \\
10 \\
\text { n.d. }\end{array}$ & $\begin{array}{c}6.0-8.0 \\
\text { to } 1.0 \\
\text { n.d. }\end{array}$ & $\begin{array}{l}\text { sub-bitiminous coal } \\
\text { meta-lignite } \\
\text { sub-bitiminous coal }\end{array}$ \\
\hline $\begin{array}{l}\text { Italy } \\
\text { Vicenza-Verona } \\
\text { Bagnasco (Piemont-Liguria } \\
\text { Basin) } \\
\text { Ribolla } \\
\text { Nuraxi Figus (Sardynia) }\end{array}$ & $\begin{array}{c}\text { Eocene } \\
\text { Oligocene } \\
\text { Miocene } \\
\text { Miocene } \\
\text { Eocene }\end{array}$ & $\begin{array}{c}1-4 \\
2 \\
2 \\
1 \\
\text { n.d. }\end{array}$ & $\begin{array}{l}\text { to } 1.5 \\
\text { n.d. } \\
1.0-8.0 \\
\text { n.d. } \\
\text { n.d. }\end{array}$ & $\begin{array}{l}\text { meta-lignite } \\
\text { meta-lignite } \\
\text { meta-lignite } \\
\text { meta-lignite } \\
\text { meta-lignite }\end{array}$ \\
\hline $\begin{array}{l}\text { Germany } \\
\text { Hirschberg i Meissner (Hesja) } \\
\text { Upper Bavaria (Penzberg) } \\
\text { Mittelbron (Badenia) }\end{array}$ & $\begin{array}{c}\text { Oligocene-Miocene } \\
\text { Oligocene } \\
\text { Upper Triassic, } \\
\text { Cretaceous }\end{array}$ & $\begin{array}{c}3-6 \\
26-31 \\
\text { several }\end{array}$ & $\begin{array}{l}26-25 \\
0.25-1.20 \\
\text { to } 1 \mathrm{~m}\end{array}$ & $\begin{array}{c}\text { meta-lignite } \\
\text { meta-lignite } \\
\text { sub-bituminous }\end{array}$ \\
\hline$\underline{\text { Sweden Heganes i Soderasen }}$ & Upper Triassic & 2 & 0.4-0.7 & meta-lignite \\
\hline $\begin{array}{l}\text { Czech Republic and Slovakia } \\
\text { Handlowa } \\
\text { Most } \\
\text { Bardiejov, Żylina }\end{array}$ & $\begin{array}{l}\text { Miocene } \\
\text { Miocene } \\
\text { Eocene }\end{array}$ & $\begin{array}{c}2 \\
3-4 \\
2-3\end{array}$ & $\begin{array}{l}2.5-12.0 \\
4.0-15.0 \\
\text { to } 0.8\end{array}$ & $\begin{array}{c}\text { meta-lignite and } \\
\text { sub-bituminous coal }\end{array}$ \\
\hline $\begin{array}{l}\text { Hungary } \\
\text { Ajka } \\
\text { Tatabanya - Dorog }\end{array}$ & $\begin{array}{c}\text { Cretaceous } \\
\text { Eocene }\end{array}$ & $\begin{array}{l}7 \\
7\end{array}$ & $\begin{array}{l}1.0-5.0 \\
\text { to } 10.0\end{array}$ & $\begin{array}{l}\text { meta-lignite } \\
\text { meta-lignite }\end{array}$ \\
\hline $\begin{array}{l}\text { Austria } \\
\text { Lunz } \\
\text { Greslen } \\
\text { Fohnsdorf }\end{array}$ & $\begin{array}{c}\text { Triassic } \\
\text { Jurassic } \\
\text { Cretaceous }\end{array}$ & $\begin{array}{l}1 \\
1 \\
1\end{array}$ & $\begin{array}{l}\text { to } 5 \mathrm{~m} \\
8.0-12.0\end{array}$ & sub-bituminous coal \\
\hline
\end{tabular}


TABLE 3 cont.

TABELA $3 \mathrm{~cd}$.

\begin{tabular}{|c|c|c|c|c|}
\hline 1 & 2 & 3 & 4 & 5 \\
\hline $\begin{array}{l}\text { Tamsweg } \\
\text { Innsbruck-Höring } \\
\text { Bavaria Basin, Alps } \\
\text { (Linz, Gosau, Horing) }\end{array}$ & $\begin{array}{l}\text { Miocene } \\
\text { Eocene- } \\
\text { Miocene } \\
\text { Oligocene }\end{array}$ & $\begin{array}{c}1-2 \\
1\end{array}$ & $\begin{array}{l}\text { to } 15.0 \\
\text { n.d. } \\
\text { to } 15 \mathrm{~m}\end{array}$ & $\begin{array}{l}\text { meta-lignite } \\
\text { sub-bituminous coal }\end{array}$ \\
\hline $\begin{array}{l}\text { Bosnia and Herzegovina } \\
\text { Zenica-Sarajewo, Sente-Rezawa, } \\
\text { Aleksinac }\end{array}$ & Early Miocene & 9 & $4.0-8.5$ & meta-lignite \\
\hline $\begin{array}{l}\frac{\text { Serbia }}{\text { Zvizd-Senje-Rasavica }} \\
\text { Sjenica-Lubnica } \\
\text { Sjenica-Soko Banja }\end{array}$ & $\begin{array}{l}\text { Cretaceous } \\
\text { Early Miocene }\end{array}$ & $\begin{array}{l}1-3 \\
3-7\end{array}$ & $\begin{array}{l}\text { to } 1.0 \\
4.5-9.0\end{array}$ & $\begin{array}{l}\text { sub-bituminous coal } \\
\text { meta-lignite }\end{array}$ \\
\hline $\begin{array}{l}\frac{\text { Romania }}{\text { Petroşani }} \\
\text { Cluj i Silvaniei }\end{array}$ & $\begin{array}{l}\text { Oligocene- } \\
\text { Miocene }\end{array}$ & $\begin{array}{c}25 \\
3\end{array}$ & $\begin{array}{c}3.5-20.0 \\
1.0\end{array}$ & sub-bituminous coal \\
\hline $\begin{array}{l}\text { Bulgaria } \\
\text { Pernik } \\
\text { Bobow Doł } \\
\text { Pirin } \\
\text { Burgas }\end{array}$ & Upper Eocene & $\begin{array}{c}3-4 \\
6 \\
4 \\
4\end{array}$ & $\begin{array}{c}0.5-6.0 \\
1.0-12.0 \\
1.0-25.0 \\
4.0\end{array}$ & $\begin{array}{l}\text { meta-lignite-sub-bitumin } \\
\text { ous coal }\end{array}$ \\
\hline $\begin{array}{l}\text { Greece } \\
\text { Thrace (Kotylii) } \\
\text { Eastern Macedonia } \\
\text { (Orestias-Elassona) } \\
\text { Peloponnese (Pyrgos) }\end{array}$ & $\begin{array}{c}\text { Paleocene } \\
\text { Oligocene } \\
\text { Lower Miocene }\end{array}$ & $\begin{array}{c}\text { a few lens } \\
2 \\
3-4\end{array}$ & $\begin{array}{l}\text { to } 0.4 \\
\text { to } 0.2 \\
0.1-0.5\end{array}$ & sub-bituminous coal \\
\hline $\begin{array}{l}\text { Russia } \\
\text { Moscov Basin } \\
\text { Bielgorod-Obojansk (Ural Basin) } \\
\text { Caspian Basin }\end{array}$ & $\begin{array}{c}\text { Lower Carboniferous } \\
\text { Upper } \\
\text { Triassic-Jurassic } \\
\text { Jurassic }\end{array}$ & $\begin{array}{c}2-3 \\
3-10 \\
2-4\end{array}$ & $\begin{array}{l}1.5-2.0 \\
\text { n.d. } \\
0.3-1.0\end{array}$ & $\begin{array}{c}\text { meta-lignite } \\
\text { meta-lignite-sub-bitumin } \\
\text { ous coal }\end{array}$ \\
\hline $\begin{array}{l}\text { Ukraine } \\
\text { so called Great Donbas - } \\
\text { Northern outskirts of Donbas } \\
\text { Basin } \\
\text { Trostyanets, Nowoselytsya, } \\
\text { Karaperowsk } \\
\text { Sambir-Chyriw }\end{array}$ & $\begin{array}{c}\text { Lower Carboniferous } \\
\text { Jurassic } \\
\text { Miocene }\end{array}$ & $\begin{array}{l}\text { to } 10 \\
\text { several } \\
\text { several }\end{array}$ & $\begin{array}{l}0.5-0.7 \\
\text { to } 1.5 \\
\text { to } 0.1\end{array}$ & sub-bituminous coal \\
\hline
\end{tabular}

n.d. - no data available. 
however, its main component is built of bituminous coal (for example the Andes Mts deposits in Bolivia, Chile, Peru, and also Mexico and the Rocky Mountains in the USA, and sometimes older Palaeozoic bituminous coal in Europe such as the Donetsk deposit in Ukraine). In Europe, Cenozoic deposits of meta-lignite and sub-bituminous coal are numerous, occurring mainly in the southern part of the continent (Fig. 2). However, they comprise small and medium sized deposits, and often they comprise only nature (uneconomic) occurrences.

The following European meta-lignite and sub-bituminous coal deposits are considered to be the most important (Table 3, Fig. 1 and 2):

- coal occurrences on the Alpine foreland and in the Alps Mts, for example in the Austrian coal basins: Fohndorf (Styria), Tamsweg, and Innsbruck-Hőring (Sachsenhofer, 2000), as well as in German coal basins Meissner-Hirschberg (Kassel) and Härong (Tyrol),

- in the Carpathians and Carpathian forelands in the northern part of Hungary (Tatabanya), in the Cluj and Silvaniei regions, as well as in Petroşani (Romania), in the

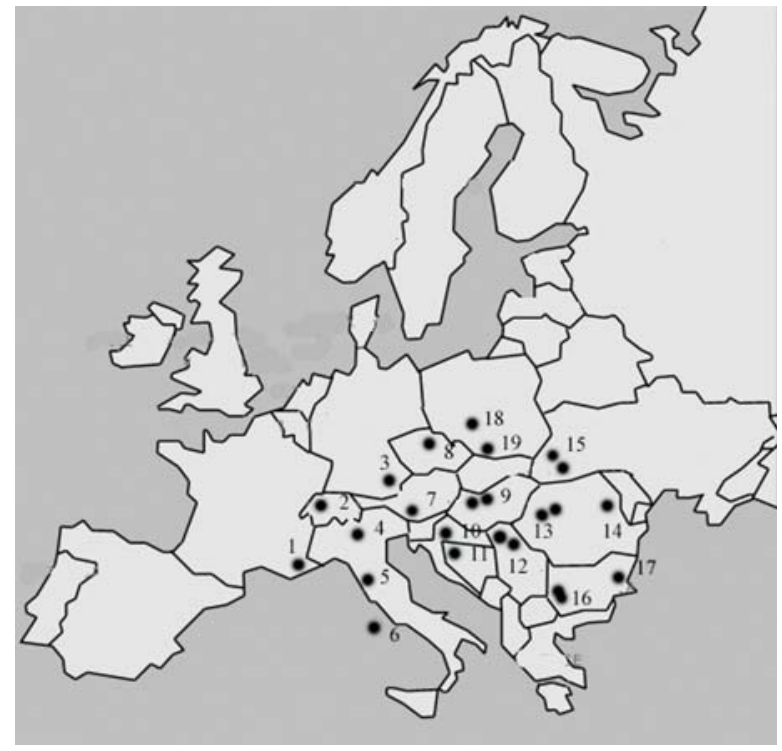

Fig. 2. Distribution of main Cenozoic meta-lignite and sub-bituminous coal deposits and their uneconomic occurrences in Europe. Coal ranking - see in Table 3

1 - Manosque (France), 2 - Limestone Alps (Switzerland), 3 - Hirschberg and Meissner (Germany),

4 - Vicenza-Verona (Italy), 5 - Bagnasco (Piemont-Ligurian Basin - Italy), 6 - Nuraxi-Figus

(Sardinia-Italy), 7 - Tamsweg-Insbruck-Höring (Austria), 8 - Handlova, Most-Żylina (Czech Republic),

9 - Kecskemet, Tatabanya-Dorog, Oroszlany (Hungary), 10 - Zenica-Sarajevo, Sente-Rezaw-Aleksinac (Bosnia and Herzegovina), 11- Zenica-Sarajevo (Bosnia and Herzegovina),

12 - Kovin-Kosovo-Kolubrara-Sjenica (Serbia), 13 - Pern-Bobowdol, Pirin (Bulgaria),

14 - Burgas (Bulgaria), 15 - Sambir-Chyriw (Ukraine), 16-17 - Silvaniei Petrosani, Cluj (Romania)

Rys. 2. Ważniejsze kenozoiczne złoża twardego węgla brunatnego i jego niezłożowe występowania w Europie. Stopień uwęglenia węgla przedstawiono w tabeli 3 
Czech Republic (Handlova and Sokolovo), and also in Ukraine (near-Carpathian region - Trostyanets, Nowoselytsya, Karaperowsk),

- the Appenines foreland (e.g. Piedmont-Ligurian deposits), in the Balkans region, e.g. Bulgarian deposits in the Perni-Pirin region, Burgas, and also deposits occurring in Bosnia-Herzegovina and Serbia. Moreover, small deposits in the mountain basins of Portugal (Combra, Abrantes), Spain (Utrillas), the French Central Massive (Du Larzac), and others.

Also of note are small but meaningful deposits and exposures of meta-lignite and sub-bituminous coal in Poland, occurring in the Zawiercie region and within the northern fringe (Northern Marginal Region) of the Holy Cross Mountains, complementing the picture of the coal bearing capacity of European Mesozoic beds.

It is difficult to assess the total volume of worldwide geological reserves of meta-lignite and sub-bituminous coal, mainly because of the various classification systems used in the individual countries in which these deposits occur. Taking into consideration the number of registered brown coal deposits exclusively with soft varieties and their industrial resources (150 million $t$ worldwide - Gawlik et al. 2004), the resources in question could comprise about $50-60$ billion $\mathrm{t}$, which is about $30 \%$ of the recognized resources of this coal. In Europe, geological resources of brown coal are estimated at 0.4 billion $t$ (loc. cit). With respect to meta-lignite and sub-bituminous coal this comprises only a small percentage of known resources.

\section{Meta-lignite and sub-bituminous coal in Poland.}

Poland is a country with a rather poor occurrence of meta-lignite and sub-bituminous coal. So far, recognized occurrences of this coal are related mainly with Mesozoic sediments and, more rarely, Cenozoic (Paleogene and Miocene). This poor coal bearing capacity results from weak coalification because of sedimentation conditions outside the Carpathian platforms both in marine Mesozoic and Paleogene; thus coal bearing peaty sediments and those known only from periods of sea regression are related to the epeirogenesis of these sea areas via development of local swamps on regressing sea shores (paralic coaly formation). In Mesozoic and Cenozoic sediments of orogene origin, i.e. in the Carpathians and their foreland, small accumulations of meta-lignite and sub-bituminous coal also occur, which can be classified only as uneconomic occurrences.

In Poland, the meta-lignite and sub-bituminous coal in domestic sediments represent a wide range of varieties. Conditions of sedimentation considered to be geotectonic geological units indicate that occurrences of the coal in question have a platform or, more rarely, orogenic character. With respect to the sedimentation environment, they are classified as limnic, limnic-fluvial, and paralic sediments, and even typical marine sediments (e.g. the Carpathian Flysch and the Podhale Trough Flysch). The layered structure of the coal, with various lithological types from xylodetritic coal to xylitic coal (meta-lignite) and from bright 
coal, via numerous varieties of banded coal, to dull coal in the case of sub-bituminous coal, is typical for limnic and paralic (brackish) conditions. Two major bright coal layers, often with fibrous coal intercalations, or more rarely fossil coaly stems of trees - actually developed as thick lenses of bright coal - have been proven in typical marine sediments of the Carpathian Flysch and partially in the Podhale Flysch. Fine coal lenses and coalified debris, often described as "cane-break", are quite frequent components of more or less coaly, sandy shales.

TABLE 4

List of currently known locations of meta-lignite and sub-bituminous coal in Poland (Wagner et al. 2008, as supplemented)

Zestawienie znanych obecnie miejsc występowania twardego węgla brunatnego w Polsce (Wagner et al. 2008, uzupełnione)

\begin{tabular}{|c|c|c|c|c|c|}
\hline No. & Occurrence & $\begin{array}{l}\text { General forms } \\
\text { of occurrence }\end{array}$ & Stratigraphy & $\begin{array}{c}\text { Variety } \\
\text { of coal ranking }\end{array}$ & $\begin{array}{c}\text { Random } \\
\text { reflectivity }[\%]\end{array}$ \\
\hline 1 & 2 & 3 & 4 & 5 & 6 \\
\hline 1 & $\begin{array}{l}\text { Northern fringe of the Holy } \\
\text { Cross Mountains } \\
\text { (Ćmielów, Bliżyn, } \\
\text { Końskich, Opoczno, } \\
\text { Chlewiska) }\end{array}$ & $\begin{array}{l}\text { lens to } 0.05 \mathrm{~m} \text {, } \\
\text { coaly plant debris }\end{array}$ & $\begin{array}{l}\text { Upper Triassic } \\
\text { (Keuperian) }\end{array}$ & $\begin{array}{l}\text { sub-bituminous } \\
\text { coal }\end{array}$ & $\mathrm{R}_{\mathrm{r}}{ }^{\mathrm{o}}=0.49-0.50$ \\
\hline $2-3$ & $\begin{array}{l}\text { Northern fringe of the Holy } \\
\text { Cross Mountains } \\
\text { (Komorów, Odrowąż, } \\
\text { Brzeście, Stefanków) }\end{array}$ & $\begin{array}{l}\text { coal beds with four } \\
\text { coal seams } \\
\text { (to about } 0.6 \mathrm{~m} \text { ) }\end{array}$ & $\begin{array}{c}\text { Upper Triassic-Early } \\
\text { Jurassic } \\
\text { (Rhaetian - Liassic) }\end{array}$ & $\begin{array}{l}\text { sub-bituminous } \\
\text { coal }\end{array}$ & $\mathrm{R}_{\mathrm{r}}{ }^{\mathrm{o}}=0.42-0.49$ \\
\hline 4 & $\begin{array}{l}\text { East European Platform } \\
\text { (Niedzica, Olsztyn, Pasłęk, } \\
\text { Kętrzyn, Pisz, Gołdap, } \\
\text { Augustów) }\end{array}$ & $\begin{array}{c}\text { coaly plant debris } \\
\text { and thin coal laminae } \\
\text { (to about } 0.01 \mathrm{~m} \\
\text { thicknesses) }\end{array}$ & $\begin{array}{c}\text { Upper Triassic - } \\
\text { Early Jurassic } \\
\text { (Rhaetian) }\end{array}$ & $\begin{array}{l}\text { sub-bituminous } \\
\text { coal }\end{array}$ & $\mathrm{R}_{\mathrm{r}}{ }^{\mathrm{o}}=0.41-0.44$ \\
\hline 5 & $\begin{array}{l}\text { Jurassic Krakow Monocline } \\
\text { (Poręba, Zawiercie, } \\
\text { Siewierz, Mierzęcice, } \\
\text { Koziegłowy, Wieluń, } \\
\text { Kalisz) }\end{array}$ & $\begin{array}{c}\text { "Blanowice" Seam } \\
\text { up to } 1.95 \mathrm{~m}\end{array}$ & Lower Jurassic & $\begin{array}{l}\text { sub-bituminous } \\
\text { coal }\end{array}$ & $\mathrm{R}_{\mathrm{r}}^{\mathrm{o}}=0.42-0.46$ \\
\hline 6 & $\begin{array}{l}\text { Mid-Poland Anticlinorium } \\
\text { (e.g. Zakrzyn IG-1, } \\
\text { Broniszew IG-1) } \\
\text { Kleszczów Trough - Łódź } \\
\text { Synclinorium (Belchatów } \\
\text { lignite deposit }\end{array}$ & $\begin{array}{l}\text { thin coal laminae } \\
\text { (up to } 0.005 \mathrm{~m} \\
\text { thicknesses) } \\
\text { thin coal laminae } \\
\text { (up to } 0.10 \mathrm{~m} \\
\text { thicknesses) }\end{array}$ & $\begin{array}{l}\text { Upper Triassic- } \\
\text { Early Jurassic } \\
\quad \text { (Rhaetian) } \\
\text { Lower Jurassic }\end{array}$ & $\begin{array}{l}\text { sub-bituminous } \\
\text { coal } \\
\text { sub-bituminous } \\
\text { coal }\end{array}$ & $\begin{array}{c}\mathrm{R}_{\mathrm{r}}{ }^{\mathrm{o}}=0.47-0.48 \\
\mathrm{R}_{\mathrm{r}}{ }^{\mathrm{o}}=0.39\end{array}$ \\
\hline 7 & $\begin{array}{l}\text { Warsaw Depression } \\
\text { (e.g. Mszczonów IG-1) }\end{array}$ & $\begin{array}{l}\text { coal laminae of } \\
\text { variable thicknesses } \\
\text { (from a milimetre } \\
\text { to about } 0.05 \mathrm{~m} \text { ) }\end{array}$ & $\begin{array}{c}\text { Cretaceous } \\
\text { (Valanginian- Upper } \\
\text { Hauterivian) }\end{array}$ & $\begin{array}{l}\text { sub-bituminous } \\
\text { coal }\end{array}$ & $\mathrm{R}_{\mathrm{r}}{ }^{\mathrm{o}}=0.46-0.48$ \\
\hline
\end{tabular}


TABLE 4 cont.

TABELA $4 \mathrm{~cd}$.

\begin{tabular}{|c|c|c|c|c|c|}
\hline 1 & 2 & 3 & 4 & 5 & 6 \\
\hline 8 & $\begin{array}{l}\text { Szczecin Synclinorium } \\
\text { (Kaleje-6, Kaleje-8, } \\
\text { Czaplinek IG) }\end{array}$ & $\begin{array}{l}\text { thin coal laminae } \\
\text { (up to } 0.01 \mathrm{~m} \\
\text { thicknesses) }\end{array}$ & as above & $\begin{array}{l}\text { meta-lignite, } \\
\text { sub-bitumonous } \\
\text { coal }\end{array}$ & $\mathrm{R}_{\mathrm{r}}{ }^{\mathrm{o}}=0.41-0.43$ \\
\hline 9 & Pomerania Anticlinorium & as above & as above & $\begin{array}{l}\text { sub-bitumonous } \\
\text { coal }\end{array}$ & $\mathrm{R}_{\mathrm{r}}^{\mathrm{o}}=0.43-0.45$ \\
\hline 11 & $\begin{array}{l}\text { North Sudetic Basin } \\
\text { (parts of Bolesławiec and } \\
\text { Lwówek Śląski) }\end{array}$ & $\begin{array}{c}\text { coal laminae and lens } \\
0.05 \mathrm{~m} \text {, in average, to } \\
\text { a maximum } 0.52 \mathrm{~m}\end{array}$ & $\begin{array}{r}\text { Cretaceous } \\
\text { (Santonian) }\end{array}$ & $\begin{array}{l}\text { sub-bitumonous } \\
\text { coal }\end{array}$ & $\mathrm{R}_{\mathrm{r}}{ }^{\mathrm{o}}=0.42$ \\
\hline 12 & $\begin{array}{l}\text { Western Carpathians } \\
\text { (Łącko Marl, Łabowa) }\end{array}$ & $\begin{array}{c}\text { xylites silicified } \\
\text { (from a fraction of } \\
\text { a milimetre to about } \\
0.2 \mathrm{~m} \text { ) }\end{array}$ & Eocene & meta-lignite & $\mathrm{R}_{\mathrm{r}}^{\mathrm{o}}=0.37$ \\
\hline 13 & $\begin{array}{l}\text { Western Carpathians } \\
\text { (Istebna beds, Magura, } \\
\text { Krosno beds) }\end{array}$ & $\begin{array}{l}\text { thin coal laminae } \\
\text { (up to } 0.01 \mathrm{~m} \\
\text { thicknesses), } \\
\text { coaly black shales }\end{array}$ & $\begin{array}{l}\text { Cretaceous } \\
\text { (Senonian - } \\
\text { Oligocene }\end{array}$ & $\begin{array}{c}\text { meta-lignite to } \\
\text { bitumonous coal }\end{array}$ & $\mathrm{R}_{\mathrm{r}}{ }^{\mathrm{O}}=0.38-0.64$ \\
\hline 13a & $\begin{array}{l}\text { Eastern Carpathians - } \\
\text { (Ropa beds, Menillite beds } \\
\text { Krosno beds) }\end{array}$ & $\begin{array}{c}\text { coal laminae and coal } \\
\text { lens (up to } 0.15 \mathrm{~m}, \\
\text { but } 0.01-0.05 \mathrm{~m}, \\
\text { on average) } \\
\text { coaly black shales } \\
\end{array}$ & $\begin{array}{l}\text { Cretaceous } \\
\text { (Cenomanian- } \\
\text { Oligocene) }\end{array}$ & $\begin{array}{l}\text { meta-lignite, } \\
\text { sub-bituminous } \\
\text { coal }\end{array}$ & $\mathrm{R}_{\mathrm{r}}^{\mathrm{o}}=0.35-0.45$ \\
\hline 14 & $\begin{array}{l}\text { Podhale Flysch Basin } \\
\text { (mostly Zakopane beds) }\end{array}$ & as above & Eocene-Oligocene & $\begin{array}{c}\text { sub-bituminous } \\
\quad \text { coal to } \\
\text { bituminous coal }\end{array}$ & $\mathrm{R}_{\mathrm{r}}^{\mathrm{o}}=0.49-1.00$ \\
\hline 15 & $\begin{array}{l}\text { Orawa Basin } \\
\text { (Orawa beds) }\end{array}$ & $\begin{array}{l}\text { bottom part of coal } \\
\text { seam from Orawa } \\
\text { Beds }(0.2 \mathrm{~m})\end{array}$ & $\begin{array}{l}\text { Miocene } \\
\text { (Badenian) }\end{array}$ & meta-lignite & $\mathrm{R}_{\mathrm{r}}{ }^{\mathrm{O}}=0.39-0.42$ \\
\hline 16 & $\begin{array}{l}\text { Carpathian Foredeep } \\
\text { (Grudna Dolna meta-lignite } \\
\text { deposit and Rzeszów Bay - } \\
\text { Skawina beds) }\end{array}$ & $\begin{array}{c}\text { coal seam } \\
\text { (but } 1.4-3.0 \mathrm{~m} \\
\text { thickness, } \\
\text { in average) }\end{array}$ & $\begin{array}{l}\text { Miocene } \\
\text { (Badenian) }\end{array}$ & $\begin{array}{l}\text { meta-lignite, } \\
\text { subbituminous } \\
\text { coal }\end{array}$ & $\mathrm{R}_{\mathrm{r}}{ }^{\mathrm{o}}=0.33-0.40$ \\
\hline 17 & $\begin{array}{l}\text { Eastern part of the } \\
\text { Carpathian Foredeep } \\
\text { (Krasna, Ryszkowa Wola, } \\
\text { and Przemyśl) }\end{array}$ & $\begin{array}{l}\text { thin coal lens } \\
\text { (up to } 0.03 \mathrm{~m} \\
\text { thicknesses) }\end{array}$ & $\begin{array}{l}\text { Miocene } \\
\text { (Badenian) }\end{array}$ & $\begin{array}{l}\text { meta-lignite, } \\
\text { subbituminous } \\
\text { coal }\end{array}$ & $\mathrm{R}_{\mathrm{r}}{ }^{\mathrm{o}}=0.38-0.42$ \\
\hline 18 & $\begin{array}{l}\text { Krzeszowice Trough } \\
\text { (Dębniki) }\end{array}$ & $\begin{array}{c}\text { coaly debris of land } \\
\text { flora, coaly leaf print } \\
\text { of land flora }\end{array}$ & $\begin{array}{c}\text { Jurassic } \\
\text { (Dogerian) }\end{array}$ & $\begin{array}{l}\text { sub-bituminous } \\
\text { coal }\end{array}$ & b.d. \\
\hline 19 & $\begin{array}{l}\text { Złoczew lignite deposit } \\
\text { (e.g. coal-well drill no. 110) }\end{array}$ & $\begin{array}{c}\text { coal seam } \\
(0.5 \mathrm{~m} \text { thickness })\end{array}$ & $\begin{array}{l}\text { Paleogene } \\
\text { (Oligocene?) }\end{array}$ & meta-lignite & $\mathrm{R}_{\mathrm{r}}{ }^{0}=0.33-0.35$ \\
\hline
\end{tabular}

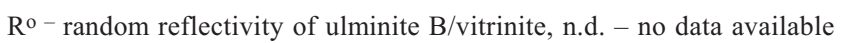


The oldest occurrence of meta-lignite and sub-bituminous coal in Poland originates from the Keuperian and Rhaetian in the northern fringe of the Holy Cross Mountains, within the region located east from Ćmielów and Kamienna, and the Czarna and Pilica rivers (Sarjusz-Makowski 1947). Meta-lignite and sub-bituminous coal has been described in the Końskie, Opoczno, and Bliżyn regions (Fig. 3). The coal bearing sediments are directly underlined by Muschelkalk Sediments, and the coal bearing formation comprises a 50-130 m thick Keuper and Rhaetic sandy rock series with rich fossil flora and coal beds of a thickness from 0.5 to $0.60 \mathrm{~m}$. In the period from 1819-1934, coal prospecting works were conducted within the Końskie region (Gromadzice, Jacentów). Usually two coal seams were found, mostly in the Zagaj beds (Rhaetic), which were $0.08-0.60 \mathrm{~m}$ thick at a depth of 15 to $50 \mathrm{~m}$. Exploitation was even conducted in the Brzeście village region (the underground "Mars Mine" with 18 shallow, small shafts, 20-30 m deep, as well as in the "Mieszała Mine" near Starachowice with a $152 \mathrm{~m}$ deep shaft), though with non-economic output.

Coal from a shallow bore hole drilled in Chlewiska near Starachowice (the author's studies, unpublished) was examined. It is a banded, bright coal of random reflectivity of

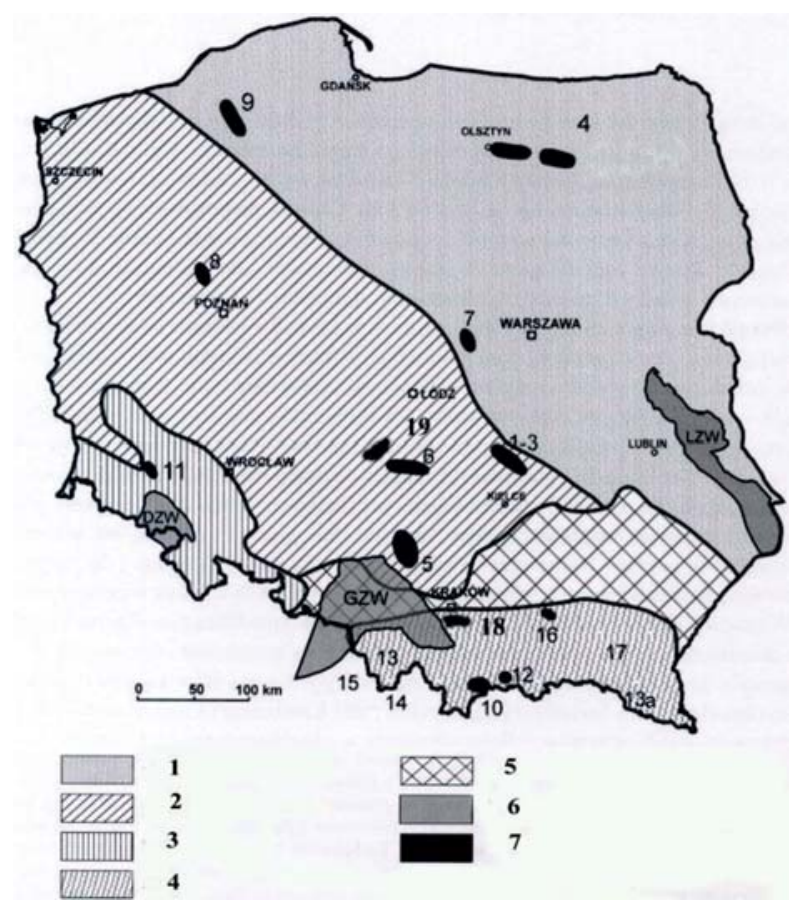

Fig. 3. The currently known locations of meta-lignite and sub-bituminous coal sampled in Poland (Wagner et al. 2008, slightly altered). The numbering of the locations - see in Table 2

1 - East European Platform, 2 - Paleozoic Platform with Permo-Cenozoic platform cover, 3 - Sudetes Mts, 4 - The Carpathians, 5 - Carpathian Foredeep, 6 - Carboniferous basins of bituminous coal,

7 - currently known locations of metalignite and subbituminous coal

Rys. 3. Obecnie znane lokalizacje złóż twardego węgla brunatnego i jego przyrodniczych nagromadzeń w Polsce (Wagner et al. 2008, nieco zmienione). Numeracja miejsc według tabeli 2 
colotelinite $\mathrm{R}_{\mathrm{r}}{ }^{\mathrm{O}}=0.49 \%$ with interesting petrographic composition, mainly telinite and telocolinite, as well as gelinite with cutinite and resinite. Telinite is composed of porous mesofile occurring between crassicutinite and gelinite, in addition to numerous aggregates of mineral wax and coaly cautchouc, probably of sub-tropical fossil flora origin. The content of

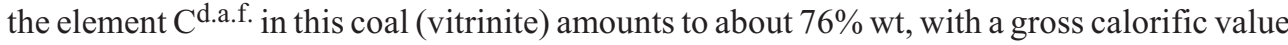
of nearly $7050 \mathrm{kcal} / \mathrm{kg}$ at $\left(\mathrm{A}^{\mathrm{d}}\right)$ ash content of about $9 \%$ (recalculated to dry basis).

Within the Starachowice and Konin region, as well as the Opoczno region, thin and irregular lenses of jet coal (exploited in the past in Zameczek) also occur within these sediments. From a petrographic point of view, the jet is defined as a bituminous form of the wood of Araucariaceae trees, which were common in Triassic and Jurassic periods. Its coal ranking corresponds to bright, sometimes dull, sub-bituminous coal, rarely meta-lignite.

Thin layers of bright varieties of the subbituminous coal were also described from Rhaetian and Lower Jurassic sediments of the East European Platform and the depression adjacent to the Teisseyere-Tornquist Line (Dadlez 1968). Coaly land flora and uncommon intercalations of bright coal in $0.01 \mathrm{~m}$ thick beds of coal have been found in the sandy-clayey sediments (Fig. 3, Table 2).

Lower Jurassic sediments are enriched with coal-bearing sediments throughout almost all of their occurrences in Poland, including sub-bituminous coal and a rich set of coaly leaf print of coaly land flora. However, accumulations of this coal have an uneconomic character. The only exception is accumulations of Lower Jurassic coal bearing sediments in the southern part of the Jurassic Krakow Monocline, from Siewierz and Zawiercie to the Częstochowa region. Brown coal from this region was examined in the 1930s. Petrologic study of coal from the Zawiercie region has been executed by Drath (1935) and supplemented by Kacprzak (1966), Kołcon, Wagner (1982), and others. The presence of 1-2 seams or a $1.5 \mathrm{~m}$ thick, single meta-lignite seam, locally up to $1.9 \mathrm{~m}$ thick under mineral cover, has been found in clayey-mudstone sediments of the so called Blanowice beds (Upper Domerian) at a thickness of about $30 \mathrm{~m}$ (Drath 1935; Kołcon, Wagner 1982; et al.). This coal has the character of banded, bright coal dominated by the vitrinite maceral group (up to $62 \%$ ). Locally, low content of the liptinite group is indicated (0.6-3.9\%), particularly sporinite, which in the past was a reason for questioning its Lower Jurassic age. It contains up to $73 \%$ of the element $\mathrm{C}^{\text {d.a.f. }}$, and up to $5.01 \%$ wt $\mathrm{H}^{\text {d.a.f. }}$, and a considerable amount of total sulphur $(3.8-9.4 \% \mathrm{wt})$. Its gross calorific value reaches $30.440 \mathrm{MJ} / \mathrm{kg}(7270 \mathrm{kcal} / \mathrm{kg})$, on average about $27.630 \mathrm{MJ} / \mathrm{kg}(6600 \mathrm{kcal} / \mathrm{kg})$, whereas random reflectivity of collotelinite $\left(\mathrm{R}_{\mathrm{r}}{ }^{\mathrm{O}}\right)$ amounts to about $0.45 \%$.

Mining exploitation of this coal was conducted before 1939 and for several years after the Second World War within the Ciagowice-Poręba region in the Zygmunt open-pit.

It is also worth mentioning the thin layers of meta-lignite and sub-bituminous coal originating from Liassic sediments occurring in the southern margin opening of the Bekchatów lignite pit. In Liassic mudstone-sandstone sediments with rich, coalified debris, thin lenses (up to $0.1 \mathrm{~m}$ ) of black coal also occur, usually weathered. Locally, its bright luster is preserved. This coal is composed only of collotelinite with telinite fragments. 
Infrequent, un-weathered parts of this coal contain $73.6 \%$ wt $\mathrm{C}^{\text {d.a.f., }}$ total moisture amounts to about 35\% wt, gross calorific value about $29.310 \mathrm{MJ} / \mathrm{kg}(7000 \mathrm{kcal} / \mathrm{kg})$, and random reflectance $\mathrm{R}_{\mathrm{r}}^{\mathrm{o}}$ 0.39-0.41\% (Kwiecińska, Wagner 2001).

There are some reports on sediments of the Middle Jurassic from the Polish Lowland regarding meta-lignite and bituminous coal occurrence. The most important of them comprises coaly debris of fossil land flora and thin laminae of meta-lignite and sub-bituminous coal in Grójec Clays and Mirów Clays (Batonian), in Dębniki near Kraków. Thin layers of bright varieties of the sub-bituminous coal were also described from the Middle Jurassic (Batonian) on the eastern Fore-Carpathians, and in other locations in the Polish Lowland area (Ciuk 1980).

The occurrence of meta-lignite and sub-bituminous coal from the Cretaceous period is known from sediments of the Lower and Upper Cretaceous of the North Sudetic Basin, from several locations within the Mid-Poland Anticlinorium and Szczecin Basin, as well as the Warszawa Synclinorium and adjacent East European Platform (Fig. 3, Table 2). In Lower Cretaceous sediments on the Polish Lowland, coal bearing sequences are encountered quite often. They are related to Middle Valanginian beds in the Szczecin Synclinorium, the Warszawa Synclinorium, and with the lower complex of the Upper Hauterivian. These are mainly thin intercalations of sandstones with coaly debris and thin $(0.01 \mathrm{~m})$ intercalations of bright coal.

In the North Sudetic Basin, near the cities of Bolesławiec and Lwówek Śląski, the coal lenses are related to the lowest and the highest horizon of the Santonian sediments. In its lower part, the lenses of metalignite and sub-bituminous coal have thickness up to $0.52 \mathrm{~m}$ (Ołdrzychów Depression), whereas in its upper part thickness is often up to $0.05 \mathrm{~m}$ (Milewicz 1962; Kołcon 1982). Intercalations and thin coal seams occur in shales, partially of coaly character. The number of coal intercalations decrease from the central part of the depression toward the east. Intercalations of gelified xylite coal actually meet in clay mines and are classified as jet coal (Kwiecińska, Jarema 2008). This coal is characterized by black colour, bright luster, and conchoidal fracture. It contains about $73-77 \%$ wt of the element $C^{\text {d.a.f. }}$

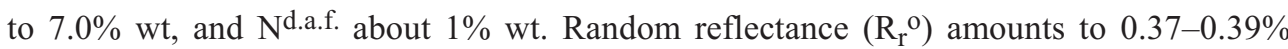
(Kołcon 1982). Net calorific value of the coal in question amounts to about $16.750 \mathrm{MJ} / \mathrm{kg}$ $(4000 \mathrm{kcal} / \mathrm{kg})$, whereas its gross calorific value amounts to about $28.260 \mathrm{MJ} / \mathrm{kg}$ (6750 kcal/kg - Kwiecińska, Wagner 2001).

Interesting locations with markings of the occurrence of autochtonic meta-lignite and sub-bituminous coal are found in sediments of the so called Aalenian and Bathonian of the Jurassic sediments of the Pieniny Klippen Belt, and also flysch sediments of the Outer Carpathians (Upper Cretaceous - Paleogene), as well as the Carpathian Foredeep sediments in their southern peripheral zone (Miocene).

Lenses of sub-bituminous coal have been described from so called "Alenian" for the Pieniny Klippen Belt, i.e. clayey-sandy sediments dated in the past as Doggerian (Sarjusz-Makowski 1947), but finally dated as Aalenian (Birkenmajer 1987; Krobicki, Wierzbowski 2004). Within the Middle Jurassic of the Skrzypne Shale Formation in Niedzica-Pruské, 
a succession coal lens with a thickness of up to $0.1 \mathrm{~m}$ has been found. This was described from the Biała Woda, Jaworki, Żabnica, and Grajcarek streams. Petrographic and chemical tests indicate sub-bituminous coal and bituminous coal presence within these sediments (Sarjusz-Makowski 1947, Wagner 1996). The description of this coal indicates that it is of black colour and bright luster, containing $75.9-85.0 \%$ wt of $\mathrm{C}^{\text {d.a.f }}$, up to $6.5 \% \mathrm{wt} \mathrm{H}^{\text {d.a.f }}$, and gross calorific value of about 29.1-30.1 MJ/kg (6950-7200 kcal $/ \mathrm{kg})$. Random reflectance of telocollinite $\left(\mathrm{R}_{\mathrm{r}}{ }^{\circ}\right)$ of this coal amounts to about $0.42 \%$; however, because of the bituminization process it is an underrated value with respect to "normal" vitrinite of type B. It should be underlined that high rate bituminous coal also occurs within these sediments in the form of Carboniferous exotic beds (the so called "block of coals" from the Biała Woda region - Makowski 1947).

From the flysch sediments of the Outer Carpathians, both Eastern and Western, meta-lignite and sub-bituminous coal of the same age as Paleogene flysch sediments of all nappes have been described, mainly from the Magura and Krosno beds (Kotlarczyk 1979; Lipiarski, Peszat 1984; Wagner 1992, 1996; et al.). The most recent reports also proved their occurrence within older sediments (for example, within various Cretaceuos stages, and within sandy shale sets with so called "cane break", i.e. within carbonaceous types of these shales with coaly debris and sometimes with thin laminae of vitrinite (Zielińska 2010). Among them, coaly, bright coal fossil stems of trees $0.1-0.4 \mathrm{~m}$ thick and up to $2 \mathrm{~m}$ long were found (Wagner 1996). Coaly stems are composed of vitrinite envelope (up to $1 / 4$ of the stem thickness), and their inside part is usually filled up with sandy, internal mould.

In the Carpathian Flysch, coal is also found from 0.03 to $0.2 \mathrm{~m}$ thick layers extending to a distance of $50 \mathrm{~m}$. Such layers have been described from Inoceramus beds in the village of Dobczyce near Myślenice (Zielińska 2010) and from the Chochołów beds of the Podhale Flysch in the village of Kosówka (Wagner 2011). They are composed exclusively of vitrinite of the bright coal $\left(\mathrm{R}_{\mathrm{r}}{ }^{\mathrm{o}}=0.48 \%\right)$ and bituminous coal (Kosówka, $\mathrm{R}_{\mathrm{r}}{ }^{\mathrm{o}}=0.66 \%-$ Table 3 ).

Thus the coal ranking of the autochthonous aggregates of the Carpathian coal is variable, changing from dull and bright brown coal to bituminous coal (Wagner 1996, 2008). Higher rank coal of these infrequent and trace coal accumulations in the Flysch Carpathians as compared with ortho-lignite from the European Lowland probably results from considerable horst-type submerging of these sediments. It cannot be excluded that the influence of frictional metamorphism of Carpathian orogen also played an essential role. Also morphologically similar and identically coalificated are sporadic coal intercalations occurring in the Podhale Flysch sediments (Frankiewicz 1974; Wagner 1996, 2011; Table. 3).

Meta-lignite deposits are known from the southern margin of the Carpathian Foredeep, among Badenian sediments (Middle Miocene), in the village of Grudna Dolna near Pilzno. Amongst blue clays, corresponding to Skawina beds with less than 2-20 m thickness of mineral cover, a 0.5 to $3.0 \mathrm{~m}$ seam of dull, sub-bituminous coal occurs which is strongly tectonically disturbed (Frankiewicz, Wagner 1982). This coal contains C d.a.f $72.6-73.1 \% \mathrm{wt}$, and its gross calorific value (Q ${ }^{\text {d.a.f. }}$ ) amounts to $28.260-28.680 \mathrm{MJ} / \mathrm{kg}(6750-6850 \mathrm{kcal} / \mathrm{kg})$. This coal was exploited during the period from 1847 to 1957. 
In his monograph, Makowski (1947) also mentioned other, numerous occurrences of hard brown coal, mainly (meta-lignite) along the northern overthrust of the Carpathians, with geological characteristics similar to the Grudna Dolna deposit. Excluding well known coal occurrences in the Nowy Sącz-Biegonice region (Nowy Sącz Basin) containing ortho-lignite, the brown coal occurrences are localized in the Podole area between Tomaszów and Lwiw (Ukraine), as well as the so called Rzeszów Gulf. The author mentions such localities as Babice, Zagłobie, Dąbrowa, Połomin, Będzimyśl near Sędziszów, and others. These are thin layers and lenses of black coal up to $0.8 \mathrm{~m}$ thick at a depth of $50 \mathrm{~m}$. They occur amongst sediments of the Middle and Lower Badenian, which is proved by well-preserved fauna.

Also known from the Carpathians Foredeep are intercalations of meta-lignite from bottom-set beds of the Badenian (Szafran, Wagner 1999), as well as from the Middle Miocene of the Orawa Basin from the Lipnica Mała region (Kołcon, Wagner 1991). In the Orawa region, an ortho-lignite seam of variable thickness (0.07-2.1 m) comprises extending lenses within Orawa beds (Middle Miocene - Badenian). In the floor layer it has distinct features of the dull variety of meta-lignite. This is indicated by total moisture content within the range of $31.0-33.0 \% \mathrm{wt}$, gross calorific value from 24.3 to $26.5 \mathrm{MJ} / \mathrm{kg}$ (5805$-6330 \mathrm{kcal} / \mathrm{kg})$, random reflectance $\left(\mathrm{R}_{\mathrm{r}}{ }^{\circ}\right)$ of ulminite $\mathrm{B}$ around $0.45 \%$, content of the element $\mathrm{C}^{\text {d.a.f }}$ of about $70-71 \% \mathrm{wt}$, and lithology features.

Sporadically, there is a probability of the occurrence of metalignite within Palaeogene sediments in the deep tectonic trough on the Polish Lowland where the ortho-lignite deposits are located. A more recent example is a sedimentary sequence (probably Oligocene) from the Złoczew lignite deposit proved in coal-well drill No 110 at a depth of $232.0 \mathrm{~m}$, i.e. at the floor of the Lower Miocene economic coal formation. Coal of a thickness of $0.5 \mathrm{~m}$, with layered xylo-detritic structure is black in colour and has a dull luster in its wet state $\left(\mathrm{W}_{\mathrm{t}}^{\mathrm{a}} \mathrm{r}=35 \% \mathrm{wt}-\right.$ total moisture, in mass percentage, recalculated to as-received basis). Random reflectance of ulminite $\mathrm{B}\left(\mathrm{R}_{\mathrm{r}}{ }^{\mathrm{O}}\right)$ amounts to $0.35-0.36 \%$, thus its coal ranking may correspond to meta-lignite.

Some observations completed from the exploited Kleszczów Fault Trough (the Bełchatów and Szczerców open-pits) also prove the presence of Paleogene sediments with thin intercalations of dull meta-lignite or bright sub-bituminous coal (Wagner 2001).

\section{Conclusions}

Meta-lignite and sub-bituminous coal, being transitory from caustobioliths into bituminous coal, is a rather rare component of sedimentary formations in Poland and Europe. It is a constituent of small, coal-bearing formations recognized in Poland and Europe in Paleozoic, Mesozoic, and Paleogene-Neogene formations.

Its presence in the sediments of Europe strongly contrasts with the coal bearing capacity of analogous sediments occurring on other continents. Meta-lignite and sub-bituminous coal is an important raw material, mostly in Asia and North America. In Europe, meta-lignite and 
sub-bituminous coal usually occurs in Triassic, Lower Crataceous (Liassic), and Paleogene, as well as sporadic Carboniferous and Cretaceous sediments. Coal bearing capacity in these periods is poor. It is caused by the predominance of marine deposits in Mesozoic and Early Cenozoic periods and younger orogenic zones of Europe. Thus, meta-lignite and sub-bituminous coal occurs here on a small or medium scale.

Cretaceous and Cenozoic deposits of meta-lignite and sub-bituminous coal in Europe are related mainly with Alpine orogenic regions. They occur in fore and intermontane depressions, and their higher coal ranking is related to magmatic phenomena, which are inherent in all phases of orogen development. Such meta-lignite and sub-bituminous coal deposits are small, and in numerous locations they occur as uneconomic deposits.

In Poland, meta-lignite and sub-bituminous coal is a constituent of Mesozoic platform sediments, and it is also present in Carpathian orogene sediments of the Carpathian depression. It also occurs sporadically in Paleogene sediments of the Polish Lowland. These are small, uneconomical geological reserves, but important with respect to their natural value for carbonisation process recognition. In orogene sediments, meta-lignite and sub-bituminous coal often have atypical features - dull varieties possess some features of bright varieties (for example luster and petrographic features) and features typical for bituminous coal (for example good coke properties). This phenomenon is poorly explained so far; in the geological sense, it reflects fast coalification as a result of block submerging, and the poorly examined influence of friction coalification related to the tectonic dynamics of mountain-building pressure.

\section{REFERENCES}

Birkenmayer K., 1987 - Stage of structural evolution of the Pieniny Klippen Belt, Carpathians. Studia Geologica Polonica 88, p. 7-32.

Ciuk E., 1980 - Les formations des lignites en Pologne et leur principaux traits lithostratigraphiques, morphologiques, chimiqueset technologiques. Przegląd Geologiczny 28, p. 250-266.

Dadlez R., 1968 - Lias i retyk na Mazurach. Kwartalnik Geologiczny t. 12, z. 3, s. 232-237.

Drath T., 1935 - Węgiel brunatny kopalni „Zygmunt” w Porębie obok Zawiercia. Państwowy Instytut Geologiczny. Warszawa.

Gabzdy l W., 1995 - Geologia Złóż Węgla. Złoża Świata. Wyd.: Polska Agencja Ekologiczna, Warszawa.

Gawlik et al. 2004 - Gawlik L., Ney R., Bla s chke W., L or en z U., 2004 - Węgiel kamienny jako źródło czystej energii w Polsce. Międzynarodowa Konferencja „Przyszłość węgla w gospodarce świata i Polski”. Katowice, s. 224-240.

Górniak K., 1997 - The role of diagenesis in the formation of kaolinite raw materials in the Santonian sediments of the North-Sudetic Trough (Lower Solesia, Poland). Applied Clay Science 12, vol. 4, p. 313-328.

Frankiewicz J., 1974 - Znaleziska eoceńskiej flory we fliszu podhalańskim grzbietu gubałowskiego. Sprawozdanie z posiedzeń KNG PAN O/Kraków t.18, z. 1, s. 321-323.

Frankiewicz J., Wagner M., 1982 - Złoże węgla brunatnego w Grudnej Dolnej, charakter węgla i możliwości jego wykorzystania. Zeszyty Naukowe AGH, Geologia z. 4, s. 67-88.

Kacprzak R., 1966 - Liasowe węgle brunatne z okolic Siewierza-Zawiercia. Przegląd Geologiczny 14, nr 10, s. 451-453. 
Krobicki M., Golonk a J., 2008 - Geological history of the Pieniny Klippen Belt and Middle Jurassic black shale as one of the oldest deposits of this region - stratigraphical position and paleoenviromental significance. Geoturystyka 2 (13), p. 3-18.

K ołc on I., 1982 - Charakterystyka twardego węgla brunatnego górnokredowego z depresji przedsudeckiej Sprawozdanie z Posiedzeń KNG PAN O/Kraków t. 26, s. 234-236.

K ołc on I., W a g n er M., 1982 - Studium petrologiczne twardego węgla brunatnego z Poręby koło Zawiercia. Kwartalnik Geologiczny t. 26, nr 3-4, s. 234-236

K o ł c o n I., W a g n e r M., 1991 - Węgiel brunatny z osadów neogenu Kotliny Orawsko-Nowotarskiej - studium petrologiczne. Kwartalnik Geologiczny t. 35, nr 3, s. 305-322.

Kotlarczyk J., 1979 - Węgiel we fliszu karpackim - kilka spostrzeżeń sedymentologicznych. Rocznik Polskiego Towarzystwa Geologicznego vol. XLIX, nr 1-2, s. 135-154.

Kowalski J., Rosiński S., 1957 - Chemia i technologia węgla brunatnego. Warszawa, PWN. Kuźniar C., 1931 - Węgle brunatne kajprowe i retyckie w Koneckiem. Posiedzenia Naukowe PIG nr 29.

Kwiecińska B., Wagner M., 2001 - Możliwość zastosowania refleksyjności jako metody badawczej w klasyfikowaniu i technologicznej ocenie jakości węgla brunatnego. Wyd. AGH Kraków, Zakład Geologii Złóż Węgla, Zakład Mineralogii, Petrografii i Geochemii.

Kw i e c ińs k a B., J a re ma B., 2008 - Występowanie gagatu w okolicy Bolesławca (górna kreda: Dolny Śląsk) Materiały XXXI Sympozjum „Geologia formacji węglonośnych”, AGH Kraków. s. 41-43.

Libicki J., Szczepański J., 2007 - Międzynarodowy System Klasyfikacji Węgli. Węgiel Brunatny 2/59, s. 3-8.

Lipiarski I., Peszat C., 1984 - Charakterystyka petrograficzna wystapień węgla w piaskowcach otryckich z kamieniołomu „Sękowiec' (oligocen pasma Otrytu). MateriałyVII sympozjum „Geologia formacji węglonośnych Polski”, AGH Kraków, s. 18-21.

Mat1 K., 1981 - Surowce mineralne świata: Węgiel brunatny. Warszawa, WG.

Milewicz J., 1962 - Facje górnej kredy wschodniej części Niecki Północnosudeckiej. Biuletyn Instytutu Geologicznego IX, 170, s 15-80.

Pendliakov I.S., 1954 - Geologija mestorożdenij ugiel. Ugletech-izdat. Moskwa.

Piw ock i M., 2004 - Budowa geologiczna Polski. Stratygrafia: kenozoik, paleogen, neogen. Niż Polski i jego południowe obrzeżenie. T. I, część 3a. Państwowy Instytut Geologiczny, Warszawa, s. 13-202.

S a chsenhofer R. F., 2000 - Geodynamic controls on deposition and maturation of coal in the Eastern Alps. Mitteilungen Österreiichische Geologische Gesellschaft, p. 185-194.

S arju sz-Makow ski A., 1947 - Węgiel brunatny w środkowej Polsce. Biuletyn PIG 40, s. 16-72.

S z a fr a n S., W a g n e r M., 1999 - Charakter petrograficzny uwęglonego materiału organicznego w mioceńskich osadach wschodniej części zapadliska przedkarpackiego. Zeszyty Naukowe Politechniki Śląskiej, Górnictwo $\mathrm{nr} 243$, s. 131-138.

Wagner M., 1980 - Utwory węglonośne jednostki magurskiej okolic Jordanowa i Nowego Sącza. Rocznik Polskiego Towarzystwa Geologicznego vol. L/1, s. 99-117.

W a g n e r M., 1992 - Studium petrologiczne węgla karpackiego równowiekowego z utworami fliszowymi, jako źródła generowania gazu ziemnego. Mineral Resources Management (Gospodarka Surowcami Mineralnymi) t. 8, z. 3-4, s. $803-816$.

Wagner M., 1996 - Petrologic studies of terrestrial organic matter in Carpathian flysch sediments, southern Poland. International Journal of Coal Geology 29, p. 259-272.

Wagner M., 2001 - Zmienność litologiczna osadów trzeciorzędu w złożu węgla brunatnego „Szczerców”. Materiały XXIV Sympozjum: „Geologia formacji węglonośnych Polski”. AGH, Kraków. s. 103-108.

W a g n er M., 2011 - Petrologic studies and diagenetic history of coaly matter in the Podhale flysch sediments, southern Poland. Annales Societatis Geologorum Poloniae vol. 81, p. 173-183.

Wagner et al. 2008 - Wagner M., Lipiarski I., Misiak J., 2008 - Atlas petrograficzny twardego węgla brunatnego i węgla kamiennego z obszaru Polski. Uczelniane Wydawnictwa Naukowo-Dydaktyczne AGH, Kraków.

Zielińska M., 2010 - Budowa petrograficzna lądowej materii organicznej we fliszu Karpat Zachodnich w Polsce. Kwartalnik AGH - Geologia 4, s. 567-584. 
WYSTĘPOWANIE TWARDEGO WĘGLA BRUNATNEGO W POLSCE NA TLE JEGO ZLÓŻ I PRZYRODNICZYCH WYSTĄPIEŃ W EUROPIE

\author{
Słowa kluczowe
}

Twardy węgiel brunatny, złoża węgla, klasyfikacja węgla brunatnego

\title{
Streszczenie
}

Węgiel brunatny dzielony jest obecnie w Polsce na miękki węgiel brunatny i wyżej uwęglony twardy węgiel brunatny. Twardy węgiel brunatny dzieli się z kolei na odmiany matowe i błyszczące. Podstawą tego podziału jest wzrastający stopień jego uwęglenia. W geologicznym nazewnictwie światowym węgiel brunatny zaliczany jest obecnie do surowców mineralnych niskouwęglonych z wydzieleniem następujących odmian: low-rank $\mathrm{C}$ orto-lignite, low-rank B meta-lignite i low rank-A subbituminous coal (norma ISO-11760).

W Polsce i Europie miękki węgiel brunatny jest podstawowym surowcem energetycznym. Jego udział w bilansie energetycznym wielu państw jest także poważny. Złoża tego węgla w Polsce i Niemczech należą do największych w Europie, tworząc atlantycką hemisferę występowania złóż węgla brunatnego.

W przeciwieństwie do tego, twardy węgiel brunatny w Europie, a także w Polsce, jest liczny w wystąpieniach, ale jego złoża i ich geologiczne zasoby są małe. W bilansie europejskich krajów jest także mało atrakcyjnym surowcem mineralnym ze względu na szczupłość jego geologicznych zasobów.

W Europie złoża twardego węgla brunatnego występują przeważnie w osadach mezozoicznych. Morskie warunki sedymentacji tych osadów nie były sprzyjające depozycji węglonośnych osadów. Powstawały one jedynie w okresach regresji mórz w określonych epokach, takich jak: dolny karbon-perm, kajper -lias, częściowo dogger i nieliczne okresy kredy. Z tych okresów zachowały się liczne, ale małe złoża węgla lub zaledwie jego przyrodnicze wystąpienia.

Złoża okresu mezozoicznego twardego węgla przeważnie mają platformowy styl budowy. Mają małą grubość formacji węglowej i zawierają niedużą ilość pokładów węgla, które jednak mogą mieć dobrą technologiczną jakość.

Najbardziej znane europejskie złoża matowego twardego węgla brunatnego to: Fuveau (Francja), Hagenes (Szwecja), Moravska Trebova i Sokolovo (Republika Czeska) oraz Biełgorod-Obojansk (Rosja). W rejestr europejskich złóż wpisane są także mezozoiczne złoża Polski: złoże Zawiercie na monoklinie krakowskiej i nieliczne miejsca występowania wzdłuż rzeki Kamiennej w północnym mezozoicznym obrzeżeniu Gór Świętokrzyskich

Kenozoiczne złoża węgla brunatnego odmian matowych i błyszczących w Europie są bardziej liczne. Ich geneza jest przeważnie orogeniczna związana z końcowym stadium powstawania gór systemu alpejskiego. Są to małe złoża węgla brunatnego ukształtowane w śródgórskich i przedgórskich tektonicznych zapadliskach.

Zjawiska magmowe systemów orogenicznych na ogół są przyczyną wyższego uwęglenia i wyższej jakości węgla.

Bardziej znane złoża twardego węgla znajdują się na terenie Alp: Monasgue - Francja, w okręgu Piemoncko-Liguryjskim (Włochy), Hirschberg i Meissner (Niemcy), w orogenie karpackim: Ajka i Tatabanya (Węgry), Silwaniei i Petroşani w Rumunii oraz ukraińskim regionie przykarpackim, a także w Bałkanach (Pirin i Perni w Bułgarii).

Polskie obszary występowania twardego węgla brunatnego tego okresu są ilościowo nieliczne. Występują w Karpatach i lokalnych nieckach śródgórskich Karpat (zapadlisko orawskie ) i w zapadlisku przedkarpackim. Są to nieprzemysłowe złoża węgla poznane w Grudnie Dolnej oraz w lokalnych obszarach wschodniej części zapadliska przedkarpackiego (po Lwów). Nieprzemysłowe wystapienia znane są także ze spągowych części warstw orawskich w Kotlinie Orawskiej w rejonie Lipnicy Wielkiej.

Podano rejestr miejsc występowania twardego węla brunatnego na terenie Polski i oceniono jego stopień uwęglenia. Głównym kryterium oceny stopnia uwęglenia był współczynnik średniej refleksyjności ulminitu B/witrynitu, pomocniczo wartości chemicznych wybranych parametrów (np. zawartość pierwiastka C, ciepło spalania). 
Jako matowy twardy węgiel brunatny (meta-lignit) uznano węgiel o refleksyjności euulminitu B od 0,33 do $0,40 \%$, natomiast twardy błyszczący węgiel brunatny (sub-bituminous coal) o wartości średniej refleksyjności witrynitu od 0,41 do $0,50 \%$.

W Polsce dotychczas stwierdzono 20 rejonów występowania tego węgla. Rejestr ten obejmuje platformowe osady mezozoiczne (rzadko kenozoiczne) i orogeniczne utwory kenozoiczne, przeważnie nie mające cech formacji węglowej (np. flisz karpacki i podhalański). Węgiel o tym stopniu uwęglenia nie ma w Polsce znaczenia ekonomicznego. Jest jednak ważnym elementem poznawczym dotyczącym teorii uwęglania i poznania paleogeografii.

\section{THE GEOLOGICAL ASPECTS OF META-LIGNITE AND SUB-BITUMINOUS COAL OCCURRENCES IN POLAND} WITHIN THE CONTEXT OF DEPOSITS AND UNECONOMIC OCCURRENCES IN EUROPE

$$
\text { Key words }
$$

Meta-lignite, sub-bituminous coal, coal deposit, low-rank coal classification

\section{Abstract}

Two types of brown coal can be distinguished in Poland - "soft brown coal" and "hard brown coal", the latter being of higher rank. Hard brown coal is divided into dull and bright types. This division is based on an increasing degree of coalification (rank). According to globally recognized nomenclature for coal technology, brown coal is categorized as a low rank energetistic raw mineral with the release of low-rank $\mathrm{C}$ ortho-lignite (soft brown coal), low-rank B meta-lignite (dull brown coal), and low-rank A sub-bituminous coal (bright brown coal - ECE UN/50, ISO-11760).

In Poland and Europe, ortho-lignite is an essential energetistic raw mineral. Its share of the energy balance of many EU member states is considerable. Deposits of ortho-lignite in Poland and Germany are among the largest in Europe, and together they comprise the Atlantic Hemisphere of brown coal deposits. In contrast, deposits of meta-lignite and sub-bituminous coal in Europe, despite its numerous occurrences, are rather small. In the balance sheet of European countries, it is not an attractive raw mineral.

In Europe, deposits of meta-lignite in Mesozoic sediments appear frosted. Marine conditions of the sedimentation of these rocks were not conducive to the deposition of coaly sediments. There were only periods of marine regression in certain epochs (brakish sediments), such as the Late Triassic (Rhaetian, Keuperian), Early Jurassic, Doggerian, and a few Cretaceous periods. From these periods numerous but small deposits of coal, or just its natural occurrence, have been preserved.

Coal deposits of Mesozoic meta-lignite are mostly in the form of cratonic construction. They are characterized by thin coal formations containing a small number of coal seams, which, however, can be thick and can have a good technological quality. The most famous European meta-lignite deposits are Fuveau-Di Larzac (France), Hagenes (Sweden), Moravska Trebova and Sokolovo (Czech Republic), and Belgorod-Obojansk (Russia). Also entered into the European register of deposits are the Mesozoic Polish deposits Zawiercie in the Krakow Monocline and the northern part of the Holy Cross Mts of the Kamienna river region.

Coal deposits of the Cenozoic Period of dull (meta-lignite) and bright (sub-bituminous coal) types in Europe are more numerous. Their genesis is mostly orogenic, related to the final stages of formation of the mountains of the Alpine system. There are small deposits of coal formed in the intermountain and foredeep tectonic zone. Igneous phenomena of orogenic systems in general are the cause of a higher rank and higher quality coal.

Well known deposits of meta-lignite and sub-bituminous coal are located in the Alps and Apenines Monasgue (France), the Piemont-Ligurian Riviera (Italy), Hirschberg and Meissner (Germany), the Carpathian Mts localites of Ajka and Tatabanya (Hungary), Silwaniei and Petroşani in Romania, the Carpathians region in Ukraine, and also in the Balkans foredeep (Pirin and Perni in Bulgaria).

There are a few Polish deposits in this period. They occur in the local intermountain basins in the Carpathians (Orawa and Nowy Sącz Basins), in the Sudetes Mts (e.g. Lusina- Udanin, Strzegom), and in the Carpathians foredeep. These are mostly small deposits of ortho-lignite. The exceptions are the non-industrial coal deposits 
Grudna Dolna and the lower parts of the deck in the Orawa-Nowy Targ Basin (LipnicaWielka), representing mainly meta-lignite.

As mentioned, there are few instances of Polish meta-lignite and sub-bituminous coal and they have no economic importance. Their classification has been carried out according to rank on the basis of existing Polish documentation as well as works of its studies. The main criterion for ranking the coal was random reflectivity $\left(\mathrm{R}_{\mathrm{r}}{ }^{\circ}\right)$ and petrologic characteristics. Coal from 0.33 to $0.40 \%$ (random reflectivity) is considered to be meta-liginite, with coal from 0.41 to $0.50 \%$ considered to be sub-bituminous coal.

In Poland, 20 regions were found. The register covers the Mesozoic deposits platform (rarely to the Cenozoic period) and orogenic deposits mostly to Cenozoic, not having the characteristics of coaly formations (e.g. the Carpathian Flysch and the Podhale Flysch sediments, southern Poland). Coal in this rank has no economic significance in Poland. However, it is an important element in the cognitive theory of coalification. 
